\title{
Effects of Soil Water Deficit on Three Tree Species of the Arid Environment: Variations in Growth, Physiology, and Antioxidant Enzyme Activities
}

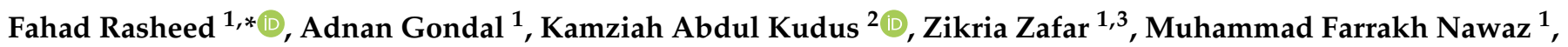 \\ Waseem Razzaq Khan ${ }^{2,4}\left(\right.$, Muhammad Abdullah ${ }^{5}$, Faridah Hanum Ibrahim ${ }^{4}$, Claire Depardieu ${ }^{6}$, \\ Ahmad Mustapha Mohamad Pazi ${ }^{2}$, Khayyam Anjum ${ }^{1}$, Shazia Afzal ${ }^{7}$, Seemab Akram ${ }^{8}$ and Mohd Nazre ${ }^{2, *}$ (D)
}

Citation: Rasheed, F.; Gondal, A.; Kudus, K.A.; Zafar, Z.; Nawaz, M.F.; Khan, W.R.; Abdullah, M.; Ibrahim, F.H.; Depardieu, C.; Pazi, A.M.M.; et al. Effects of Soil Water Deficit on Three Tree Species of the Arid Environment: Variations in Growth, Physiology, and Antioxidant Enzyme Activities. Sustainability 2021, 13, 3336. https://doi.org/10.3390/ su13063336

\section{Academic Editor:}

Manuel López-Vicente

Received: 20 November 2020

Accepted: 18 January 2021

Published: 18 March 2021

Publisher's Note: MDPI stays neutral with regard to jurisdictional claims in published maps and institutional affiliations.

Copyright: (c) 2021 by the authors. Licensee MDPI, Basel, Switzerland. This article is an open access article distributed under the terms and conditions of the Creative Commons Attribution (CC BY) license (https:// creativecommons.org/licenses/by/ $4.0 /)$.
1 Department of Forestry \& Range Management, University of Agriculture, Faisalabad 38040, Pakistan; adnangonda1856@gmail.com (A.G.); zikria.zafar@forst.uni-goettingen.de (Z.Z.); farrakhnawaz@uaf.edu.pk (M.F.N.); khayyamanjum.anjum63@gmail.com (K.A.)

2 Department of Forestry Science and Biodiversity, Faculty of Forestry and Environment, Universiti Putra Malaysia, Sri Serdang 43400, Selangor, Malaysia; kamziah@upm.edu.my (K.A.K.); khanwaseem@upm.edu.my (W.R.K.); muss.pazii@gmail.com (A.M.M.P.)

3 Department of Forest Genetics and Forest Tree Breeding, University of Göettingen, Büsgenweg 2, 37077 Göttingen, Germany

4 Institut Ekosains Borneo, Universiti Putra Malaysia Kampus Bintulu, Bintulu 97008, Sarawak, Malaysia; f_hanum@upm.edu.my

5 Cholistan Institute of Desert Studies (CIDS), The Islamia University of Bahawalpur, Bahawalpur 63100, Pakistan; abdullahfrw@iub.edu.pk

6 Canada Research Chair for Forest Genomics, Institute for Systems and Integrative Biology, Université Laval, Québec, QC G1V 0A6, Canada; claire-paulette.depardieu.1@ulaval.ca

7 Department of Forestry, University of Sargodha, Sargodha 40100, Pakistan; shazia.afzal@uos.edu.pk

8 Department of Biology, Faculty of Science, Universiti Putra Malaysia, Sri Serdang 43400, Selangor, Malaysia; seemabakram@ymail.com

* Correspondence: fahad.rasheed@uaf.edu.pk (F.R.); nazre@upm.edu.my (M.N.)

Abstract: Low water availability predicted under climate change is a major abiotic factor limiting plants growth and productivity. In this study a greenhouse experiment was conducted on three important tree species of arid environment: Conocarpus erectus (CE), Acacia modesta (AM), and Salix tetrasperma $(S T)$. Young saplings were subjected to control (C), medium (MWD) and severe soil water deficit (SWD) treatments and response was evaluated. Results showed that in all the three species leaf, stem and root dry weight production remained similar to C under MWD treatment but decreased significantly under SWD. The highest decrease in total dry weight was noticed in ST and the lowest was evidenced in $A M$ under SWD. Root:shoot ratio increased significantly in both CE and AM under MWD and SWD. Furthermore, chlorophyll content decreased while proline content increased significantly in both MWD and SWD treatments. The production of oxidants (hydrogen peroxide and superoxide anions) and antioxidants (superoxide dismutase, catalase, peroxidase and ascorbate peroxidase) increased significantly under both MWD and SWD treatments and were the highest in AM in both MWD and SWD treatments. Therefore, we may conclude that all the three species can tolerate medium water stress due to increased root production and an effective antioxidant defense mechanism.

Keywords: Conocarpus; Acacia; Salix; biomass production; proline content; reactive oxygen species; drought

\section{Introduction}

Globally, climate change induced drought has become a major threat to plant productivity [1]. However, uncertainty still remains in predicting the duration of drought spells [2]. According to an estimate, $36 \%$ of the world's area falls under arid to semi-arid climate that receives $50-150 \mathrm{~mm}$ of rainfall annually and the remaining $64 \%$ area is experiencing seasonal drought spells [3]. In this scenario, where tree species are growing within narrow 
hydraulic limits, species may face long term reduction in growth and productivity [4]. One of the solutions is to explore adaptability of tree species to various abiotic stress that has been the focus of many previous studies over the past decade [5-7].

Plant generally response to drought stress by decreasing growth and adjusting various physiological processes like stomatal conductance and net $\mathrm{CO}_{2}$ assimilation rate $[8,9]$. Increase in root biomass has also been observed in some species as a strategy to avoid drought stress [10]. During the early stage of water stress, plants maintain the leaf water potential and $\mathrm{CO}_{2}$ assimilation rate by decreasing stomatal conductance [11]. However, under severe and prolonged water stress, excessive decrease in stomatal conductance may result in decrease in $\mathrm{CO}_{2}$ assimilation rate [7,12]. In addition, plants strive to maintain the water balance under drought stress by excessive production of proline and soluble sugars that helps maintaining the osmotic pressure in the cytoplasm [11]. Moreover, production of proline and carbohydrates delays protein denaturation and cell membrane damage by inducing enzymatic proteins thus, preserving their proper functioning [13]. Changes in biochemical mechanisms are also a major part of the plant response to various environmental stresses [14]. Such a response includes increased production of reactive oxygen species (ROS) in the form of superoxide anions $\left(\mathrm{O}^{2-}\right)$, singlet oxygen $\left({ }^{1} \mathrm{O}_{2}\right)$, hydroxyl radicals $(\mathrm{OH})$, hydrogen peroxide $\left(\mathrm{H}_{2} \mathrm{O}_{2}\right)$, and alkoxy radicals $(\mathrm{RO})$. Overproduction of these oxidants damages the cell membrane, proteins, lipids and nucleic acids and sometime may lead to cell death under severe conditions $[15,16]$. Plants respond to an excess of oxidants by producing different antioxidants that balance the over production of ROS [17]. The most important antioxidant enzymes are superoxide dismutase (SOD), catalase (CAT), peroxidase (POD), and ascorbate peroxidase (APX) to prevent cell damage $[18,19]$. SOD converts $\mathrm{O}^{2-}$ into $\mathrm{H}_{2} \mathrm{O}_{2}$ and $\mathrm{O}_{2}$, and CAT and POD scavenge $\mathrm{H}_{2} \mathrm{O}_{2}$ into $\mathrm{H}_{2} \mathrm{O}[20,21]$. The production of these antioxidants strengthens the stress tolerance capabilities in plants subjected to a long-term drought stress [16]. However, such adjustments, in growth, physiological parameters and biochemical mechanisms depend on the severity, duration of stress, and species in question [7,21-23].

In Pakistan, about 7.8 Mha falls under arid and semiarid climate where fluctuating precipitation patterns has become a serious threat to forest cover [24]. In this scenario, species may face decrease in productivity or mortality under severe conditions, given that the water availability continues to decrease at the current pace [25]. Consequently, it has become a challenge to meet the demand and supply gap of timber and fuel wood and to protect the natural vegetation and wildlife [26]. Therefore, in the current scenario, where diminishing water supply has become a known fact, evidencing the response of tree species to soil water deficits can be important to sustain productivity and meet the increase demand of timber and fuel wood. Conocarpus erectus commonly called buttonwood, belongs to the Combretaceae family and normally exists on shoreline in tropical and subtropical areas of the globe [25]. Conocarpus erectus can tolerate various environmental stresses such as drought [27] therefore, the species is commonly being used for afforestation in arid as well as semi-arid regions [28]. Acacia modesta is a medium size tree that belongs to the Mimosaceae family. Acacia modesta has the ability to grow in various types of soil and is present in different parts of Pakistan, including Punjab, North-West Frontier Province, and Baluchistan, as well as different parts of India [29]. The Genus Salix belonging to the Salicaceae family and has medicinal and timber value. The species is widely cultivated in many countries [30]. Salix also produces phenolic compounds that play an important role in reducing stress provoked by biotic and abiotic factors [31]. However, mature trees can tolerate water stress, but young saplings are very sensitive to abiotic factors, especially drought. Therefore, to ensure a high survival percentage in the tree plantation programs, evidencing drought tolerance in various tree species, especially at sapling stage, is pre-requisite. Therefore, in this study, we aim to assess the water stress tolerance of three important tree species of arid environments: Conocarpus erectus (CE), Acacia modesta $(A M)$ and Salix tetrasperma (ST). Morphological, physiological along with the biochemical response mechanisms were evidenced under three levels of soil water deficit under controlled conditions. Evaluating stress tolerance in these three tree species at young sapling stage may help in recommending species for tree plantation in areas with low water availability. 


\section{Materials and Methods}

\subsection{Planting Material and Growth Conditions}

A pot experiment was conducted in the green house at Forest Nursery $\left(31^{\circ} 26^{\prime} \mathrm{N}, 73^{\circ} 06^{\prime} \mathrm{E}\right.$; $184.4 \mathrm{~m}$ ), Department of Forestry \& Range Management, University of Agriculture Faisalabad Pakistan during spring 2018. Forty-five, 3-4 months old healthy saplings of three tree species i.e., Conocarpus erectus (CE), Acacia modesta (AM) and Salix tetrasperma (ST), were obtained from forest nursery and after one week of acclimatization, saplings were transplanted (one seedling per pot) into $10 \mathrm{~L}$ plastic pots. Pots were filled with $10 \mathrm{~kg}$ sandy loam soil and farmyard manure in 3:1 ratio at field capacity (FC). Three soil cores of $100 \mathrm{~g}$ were taken, and oven dried to measure the soil moisture contents which were $36.1 \mathrm{~g}$ at field capacity. The data was used to calculate the pot weight at 80,60 and $40 \%$ of field capacity which was $9280 \mathrm{~g}, 8560 \mathrm{~g}$, and $7840 \mathrm{~g}$, respectively. The physio-chemical properties of soil were determined and are given in Table 1. Slow-release fertilizer (Nutricote, Chanan Din Seeds, Lahore, Pakistan) was added to each pot at $5 \mathrm{~g}$ per month having N-P-K at $15-5-5 \%$, respectively.

Table 1. Physio-chemical properties of soil used in study.

\begin{tabular}{ll}
\hline Properties & Values \\
\hline $\mathrm{pH}$ & 6.5 \\
Electrical conductivity $\left(\mathrm{dS} \mathrm{m}^{-1}\right)$ & 2.5 \\
Total soluble solids (TSS) & 14.2 \\
Nitrogen $(\%)$ & 0.046 \\
Phosphorus (ppm) & 9.8 \\
Organic matter content (\%) & 8.91 \\
Soil saturation percentage $(\%)$ & 36 \\
Sand (\%) & 69 \\
Silt (\%) & 18.5 \\
Clay (\%) & 12.5 \\
Texture class & Sandy loam \\
\hline
\end{tabular}

Five saplings of each species were randomly assigned to either control condition (C; $80 \%$ of FC), medium water stress (MWD; $60 \%$ of FC) and severe water stress (SWD; $40 \%$ of FC) treatment. Soil water deficit in each treatment was maintained by adding water and bringing pot weight to reference weight every alternate day. Soil moisture contents were also measured by using the soil moisture meter TRIME-EZ/-IT (IMKO Micromodultechnik GmbH, Ettlingen Germany). During the experiment, average day and night temperature and relative humidity in the green house varied between $25-35^{\circ} \mathrm{C}$ and $50-65 \%$, respectively. The experiment continued for period of 90 days under a completely randomized design (CRD).

\subsection{Growth and Dry Weight Production in Various Plant Sections}

Plant height $(\mathrm{cm})$, stem diameter $(\mathrm{mm})$ and number of leaves were measured at the beginning and at the end of the experiment. At the end of the experiment plants were removed from the pots and were dissected into shoot and root sections. Shoot section of each plant was further divided into leaves and stem, stored in paper bags, and properly tagged for identification. Root section of each plant was gently washed with tap water, stored in paper bags and properly tagged. Subsequently, each leaf, stem and root section were dried at $70{ }^{\circ} \mathrm{C}$ till constant weight and dry weight production of each plant section and total dry weight was computed [30]. The root/shoot ratio (R:S ratio) of each plant was calculated as a ratio between root dry weight and leaves and stem dry weight.

\subsection{Determination of Chlorophyll, Total Phenolic and Proline Contents}

Fully mature, healthy and undamaged leaves of each plant were collected at the end of the experiment. Leaves were washed with distilled water and stored at $-80^{\circ} \mathrm{C}$ for further analyses. Chlorophyll contents were extracted from $0.5 \mathrm{~g}$ of fresh leaf sample using acetone 
and distilled water $(80 \%, v / v)$ and centrifugation at $13,000 \mathrm{rpm}$ [32]. Supernatant was then collected, and absorption was measured at 470,645 , and $663 \mathrm{~nm}$ using a spectrophotometer (Eppendrof BioSpectrometer ${ }^{\circledR}$ basic; Hamburg, Germany). Soluble sugars and proline content were determined in three leaves per species per treatment. The total phenolic contents (TPC) in the leaf sample were determined using Folin-Ciocalteu reagent [33]. Proline content in the fresh leaves samples was determined by the ninhydrin method [34].

\subsection{Determination of Cellular Damage}

Concentration of Malondialdehyde (MDA) was determined following Hodge [35]. Electrolyte leakage (EL) was determined in $100 \mathrm{mg}$ fresh leaf samples that were placed in test tubes containing $10 \mathrm{~mL}$ deionized water. The tubes were placed in a water bath at $32{ }^{\circ} \mathrm{C}$ and after two hours, the initial electrical conductivity was measured. Subsequently, the samples were placed in a heat oven at $100{ }^{\circ} \mathrm{C}$ for $20 \mathrm{~min}$ and after cooling, the final electrical conductivity was measured. EL \% percentage was calculated using the following equation

$$
\mathrm{EL}(\%)=\mathrm{EC}_{\mathrm{i}} / \mathrm{EC}_{\mathrm{f}} \times 100
$$

where $\mathrm{EC}_{\mathrm{i}}$ and $\mathrm{EC}_{\mathrm{f}}$ is the initial and final electrical conductivity, respectively [36].

\subsection{Concentration of Reactive Oxygen Species (ROS) and Antioxidant Enzymes}

Concentration of hydrogen peroxide $\left(\mathrm{H}_{2} \mathrm{O}_{2}\right)$ was measured as described by Velikova [37]. Leaf samples of each plant $(0.5 \mathrm{~g})$ were extracted in an ice bath with $5 \mathrm{~mL}$ of $0.1 \%$ trichloroacetic acid and were centrifuged at $12,000 \mathrm{rpm}$ for $15 \mathrm{~min} .1 \mathrm{~mL}$ of supernatant was added to $1 \mathrm{~mL}$ of $10 \mathrm{mM}$ potassium phosphate buffer ( $\mathrm{pH} 7.0)$ and $2 \mathrm{~mL}$ of $1 \mathrm{M}$ potassium iodide and was placed in dark condition for one hour. The absorbance curve of the supernatant was measured using a spectrophotometer at $390 \mathrm{~nm}$ (Eppendorf BioSpectrometer ${ }^{\circledR}$ basic; Hamburg, Germany). Superoxide radical $\left(\mathrm{O}^{2-}\right)$ concentration in tissue was determined in accordance with [38]. Activities of superoxide dismutase (SOD), catalase (CAT) and peroxidase (POD) were determined in each plant following the method of [39]. One unit of SOD activity was defined as the amount of enzyme required to produce a 50\% inhibition of nitroblue tetrazolium (NBT) at $560 \mathrm{~nm}$ (Eppendorf BioSpectrometer ${ }^{\circledR}$ basic; Hamburg, Germany). Ascorbate peroxidase (APX) activity was determined following the protocols reported in [40].

\subsection{Statistical Analysis}

Residuals were checked for homoscedasticity and normality by using Q-Q plots. Variables were analyzed using two-way ANOVA for species (S-effect), treatment (T-effect) and interaction effect $(\mathrm{S} \times \mathrm{T}$ effect). Differences between means were tested using post-hoc Tukey's HSD test. Means are presented with their standard errors $( \pm \mathrm{SE})$ and differences were considered significant at $p<0.05$. All analysis was run in Statistica 12.5 software (Statsoft, Maisons-Alfort, France).

\section{Results}

\subsection{Effects of Soil Water Deficit on Growth and Physiological Parameters}

Soil water deficit had a significant negative impact on the growth traits i.e., plant height, stem diameter and number of leaves (Table 2). Mean plant height, stem diameter and number of leaves remained similar to control under MWD and decreased significantly by $24.5,19.5$, and $28.3 \%$, respectively under SWD as compared to control. In SWD treatments, the highest decrease in mean plant height, stem diameter and number of leaves was noticed in ST $(29,25$, and $37 \%$, respectively) and the lowest decrease was noticed in AM $(19,13.5$, and $22 \%$, respectively) as compared to control. 


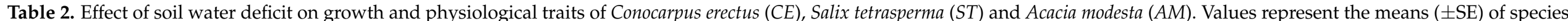

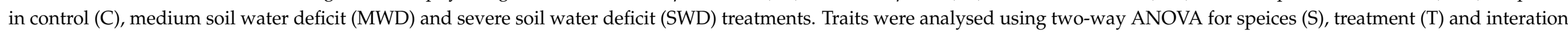
effect $(\mathrm{S} \times \mathrm{T})$. Small letters represent pair wise differences between treatments tested using post-hoc Tukey's test. All tests are taken significant at $p<0.05$.

\begin{tabular}{|c|c|c|c|c|c|c|c|c|c|c|c|c|}
\hline \multicolumn{4}{|c|}{ Conocarpus erectus (CE) } & \multicolumn{3}{|c|}{ Salix tetrasperma $(S T)$} & \multicolumn{3}{|c|}{ Acacia modesta $(A M)$} & \multirow[b]{2}{*}{ S-Effect } & \multirow[b]{2}{*}{ T-Effect } & \multirow[b]{2}{*}{$\mathbf{S} \times \mathbf{T}$ Effect } \\
\hline Traits & $\mathrm{C}$ & MWD & SWD & C & MWD & SWD & C & MWD & SWD & & & \\
\hline Plant height $(\mathrm{cm})$ & $37(1.51) \mathrm{a}$ & $32.3(1.20) \mathrm{a}$ & $28.6(1.20) \mathrm{b}$ & $35.5(0.86) \mathrm{a}$ & $32.5(0.76)$ a & $25.1(0.60) \mathrm{c}$ & $19.5(0.86) \mathrm{c}$ & $17.5(0.50) \mathrm{c}$ & $15.8(0.60) \mathrm{d}$ & $<0.001$ & $<0.001$ & $<0.001$ \\
\hline Stem diameter $(\mathrm{mm})$ & $4.83(0.33) \mathrm{a}$ & $4.25(0.25) \mathrm{a}$ & $3.88(0.22) \mathrm{c}$ & $5.11(0.07) \mathrm{a}$ & $4.85(0.14) \mathrm{a}$ & $3.83(0.16) \mathrm{c}$ & $4.80(0.15)$ a & $4.66(0.16)$ a & $4.15(0.05) b$ & $=0.235$ & $<0.001$ & $<0.001$ \\
\hline Number of leaves & $54.3(2.02) \mathrm{bc}$ & $49.6(2.88) \mathrm{c}$ & $38.3(1.45) \mathrm{d}$ & $37(1.15) \mathrm{d}$ & $34.6(1.20) \mathrm{e}$ & $23.3(1.88) \mathrm{f}$ & $72.0(2.64)$ a & $65.6(1.76) \mathrm{b}$ & $55.6(1.20) \mathrm{bc}$ & $<0.001$ & $<0.001$ & $<0.001$ \\
\hline Chl. content $\left(\mu \mathrm{mol} \mathrm{g}^{-1} \mathrm{fw}\right)$ & $5.12(0.06) \mathrm{cd}$ & $4.36(0.09)$ ef & $3.32(0.18) \mathrm{f}$ & $6.48(0.14) \mathrm{a}$ & $5.58(0.17) \mathrm{bc}$ & $4.88(0.07) \mathrm{de}$ & $5.78(0.08) \mathrm{b}$ & $4.37(0.09)$ ef & $3.55(0.11) \mathrm{f}$ & $<0.001$ & $<0.001$ & $<0.001$ \\
\hline $\operatorname{TPC}\left(\mu \mathrm{g} \mathrm{g}^{-1} \mathrm{fw}\right)$ & $250(4.39) \mathrm{b}$ & $228(1.87) \mathrm{c}$ & $187(2.99) \mathrm{d}$ & $277(2.92) \mathrm{a}$ & $217(7.91) \mathrm{c}$ & $174(7.50) \mathrm{e}$ & 144 (1.44) ef & $109(1.73) \mathrm{f}$ & $84(1.84) \mathrm{g}$ & $<0.001$ & $<0.001$ & $<0.001$ \\
\hline Proline content $\left(\mathrm{mmol} \mathrm{g}^{-1} \mathrm{fw}\right)$ & $44.0(0.96) \mathrm{bc}$ & $48.4(1.34) \mathrm{b}$ & $60.1(1.20)$ a & $39.1(0.71) \mathrm{c}$ & $41.0(1.09) \mathrm{c}$ & $57.7(1.77) \mathrm{a}$ & $38.9(0.83) \mathrm{c}$ & $39.9(1.01) \mathrm{c}$ & $57.4(0.87)$ a & $<0.001$ & $<0.001$ & $<0.001$ \\
\hline $\mathrm{R}: \mathrm{S}$ ratio & $0.77(0.01) \mathrm{c}$ & $0.80(0.01) \mathrm{bc}$ & $0.84(0.03) \mathrm{b}$ & $1.02(0.03) \mathrm{a}$ & $1.08(0.02) \mathrm{a}$ & $0.92(0.01) \mathrm{b}$ & $0.47(0.01) \mathrm{e}$ & $0.53(0.01) \mathrm{d}$ & $0.46(0.01) \mathrm{e}$ & $<0.001$ & $<0.001$ & $<0.001$ \\
\hline
\end{tabular}


Physiological traits like mean chlorophyll content (Chl. content) and total phenolic content (TPC) also decreased significantly by $15.3 \%$ and $30.8 \%$ in MWD and further decreased by $49.5 \%$ and $44.1 \%$, respectively under SWD treatment as compared to control (Table 2). In both MWD and SWD treatments, the highest decrease in mean Chl. content and TPC was noticed in AM ( $24 \%$ and $24.3 \% ; 38 \%$ and $41 \%$, respectively), and the lowest decrease was noticed in ST ( $13.8 \%$ and $21.6 \% ; 25 \%$ and $37 \%)$, respectively as compared to control. Mean proline content remained similar to control in MWD and increased by $43.4 \%$ in SWD treatment. In SWD, the highest increase in mean proline content was noticed in $\mathrm{AM}(47.5 \%)$ and the lowest increase was noticed in CE (36.5\%) as compared to control.

\subsection{Effects of Soil Water Deficit on Dry Weight Production in Various Plant Sections}

Treatment effect was found significant for the dry weight production in leaves, stem and roots (Figure 1). Mean stem and root dry weight remained similar to control under MWD while mean leaf dry weight decreased significantly by $8 \%$ under MWD treatment (6.6\% decrease in CE). In SWD treatment, a significant decrease of was noticed in leaf, stem and roots as compared to control. Mean leaf, stem and roots dry weight decreased by $33 \%$, $28.4 \%$, and $31 \%$, respectively as compared to control. In SWD treatment, ST was found the most sensitive species with the highest decrease in mean leaf $(38 \%)$, stem $(32 \%)$ and root $(39 \%)$ dry weight production, respectively as compared to control (Figure 1). The lowest decrease was evidenced in AM with $23 \%$ decrease in leaf, $24 \%$ in stem and $24 \%$ in root dry weight production, respectively. Mean total dry weight remained similar to control under MWD treatment however, decreased significantly by 30.6\% under SWD treatment, as compared to control. In SWD treatment, ST was found highly sensitive with the greatest decrease in total dry weight (36.9\%) followed by CE (29.5\%). The lowest decrease in total dry weight production was observed in AM (23.5\%) as compared to control. R:S ratio differed significantly across the treatments. The R:S ratio increased significantly in all the species under MWD treatment as compared to control, however, decreased significantly in ST under SWD (Table 2).

\subsection{Effects of Soil Water Deficit on ROS Production and Electrolyte Leakage}

The production of ROS increased significantly in all the species grown under MWD and SWD treatment as compared to control. $\mathrm{H}_{2} \mathrm{O}_{2}, \mathrm{O}^{2-}$, MDA and EL showed a significant increase of $6.2,34,22.2$ and $30.8 \%$, respectively under MWD as compared to control. The production of $\mathrm{H}_{2} \mathrm{O}_{2}, \mathrm{O}^{2-}$, MDA and EL further increased by 15.1, 84.9, 48.7, 83.2\%, respectively under SWD treatment as compared to control. In MWD treatment, the highest increase in $\mathrm{H}_{2} \mathrm{O}_{2}, \mathrm{O}^{2-}$, MDA and $\mathrm{EL}$ of $8.9,98,41.9$ and $44.6 \%$, respectively was noticed in $\mathrm{AM}$ and the lowest increase was noticed in $\mathrm{CE}$ which remained at 3.9, 7.3, 6.8 and $15.3 \%$, respectively as compared to control. Similarly, in SWD treatment, increase in $\mathrm{H}_{2} \mathrm{O}_{2}$, $\mathrm{O}^{2-}$, MDA and EL was maximum in AM $(13.7,172,84$, and $92 \%$, respectively) and was minimum in $\mathrm{CE}(10.5,72,29.8$, and $60 \%$, respectively) as compared to control.

\subsection{Effects of Soil Water Deficit on Antioxidant Enzymes Activity}

Antioxidant enzyme activity increased significantly in all the species under MWD and SWD treatments as compared to control (Table 2). Concentration of all antioxidants like SOD, POD, CAT and APX increased by $21.8,65,14.3$, and $24.4 \%$ under MWD treatment as compared to control. The concentration of SOD, POD, CAT and APX further increased by $60.5,146,56.5$ and $74.4 \%$, respectively under SWD treatment as compared to control. In MWD treatment, the increase in concentration of SOD, POD and CAT was highest in AM (28.6, 32.9 and $57 \%$, respectively) and was lowest in ST (12.3, 13.1 and $2.6 \%$, respectively) as compared to control. Similarly, in SWD treatment, increase in concentration of SOD, POD and CAT was the highest in AM (32, 406 and $225 \%$ respectively) and was the lowest in ST (37.2, 48.8, and $17.6 \%$, respectively) as compared to control. Unlike other antioxidant enzymes, concentration of APX was found the highest in ST under both MWD and SWD ( $59.4 \%$ and $137 \%$, respectively) as compared to control. 

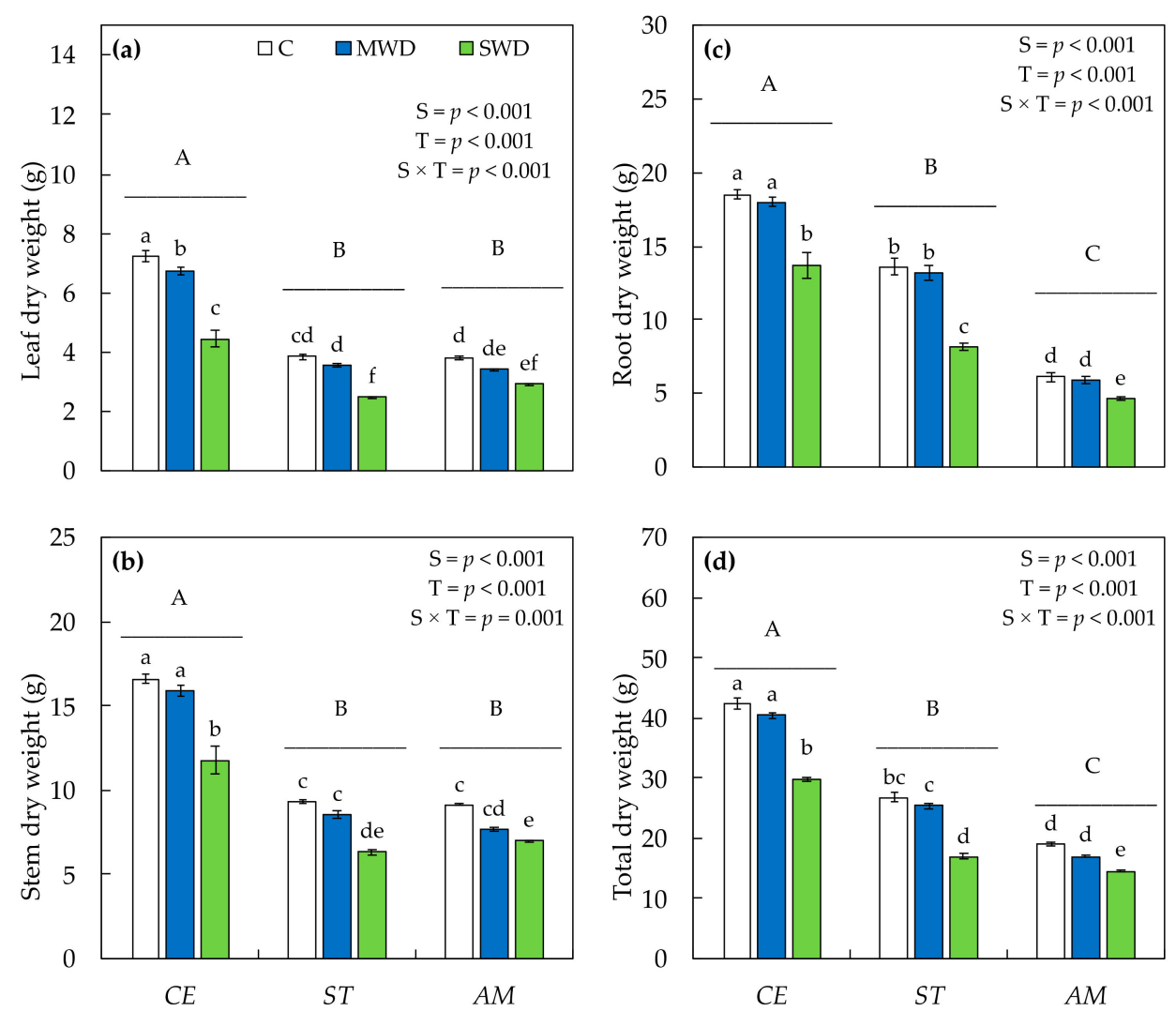

Figure 1. Mean dry weight production in various plant sections (a) leaf, (b) stem, (c) root and (d) total of Conocarpus erectus (CE), Salix tetrasperma (ST) and Acacia modesta (AM) under control (C), medium soil water deficit (MWD) and severe soil water deficit (SWD) treatments. Traits were analysed using two-way ANOVA for species $(\mathrm{S})$, treatment $(\mathrm{T})$ and interation effect $(\mathrm{S} \times \mathrm{T})$. Small letters represent pair wise differences between treatments and capital letters represent significant differences among species tested using post-hoc Tukey's test. Error bars are the standard errors.

\section{Discussion}

\subsection{Effect of Soil Water Deficit on Plant Productivity}

In this study, no stress symptoms such as curling or wilting of leaves were evidenced in any of the treatment. However, all the species showed a significantly reduction in growth and dry weight production in leaves, stem and roots but only under SWD treatment (Figure 1). The highest decrease in total dry weight was found in Salix tetrasperma and the lowest was found in Acacia modesta which suggests that at sapling stage, Acacia modesta is less sensitive to water deficit as compared to the other two species. These results are consistent with the previous observations on Conocarpus, Salix, Ziziphus and Betula species, where a significant reduction on growth and biomass production has been reported under water stress $[6,7,10,31]$. The reduction in morphological attributes under water deficit conditions are often linked to the shrinkage of cell volume due to low turgor pressure which is sometimes accompanied with leaf senescence [7,41]. Similarly, in the previous studies on Conocarpus and Ficus species, significant decrease in transpiration rate, that may influence the water and nutrient uptake from the soil matrix under water deficit, has been the principal cause of reduction in growth [10]. Our results support this hypothesis as the significant decrease in total dry weight was only observed under SWD and not under MWD. Root morphology is also important in determining the ability of a species to survive under water stress [42,43]. In this study, R:S ratio increased significantly in all three species under MWD and decreased significantly only in ST under SWD. These results are in agreement with the previous studies where drought tolerant species exhibited an increase in R:S ratio as compared to non-tolerant species [7,44]. Such morphological 
adaptations help plants in sustaining water uptake under water stress environment [45]. In this study, plants exposed to the water deficit also exhibited the significant reduction in chlorophyll content (Table 2). The reduction in chlorophyll content is regarded as a common response following abiotic stress $[9,23,46]$, that results in reduced photosynthesis and assimilation rate under water stress [12]. Decrease in chlorophyll contents under drought stress is mainly due to chloroplasts damage caused by the over production of ROS [47]. In this study, significant increase in EL percentage under both MWD and SWD support this argument. Such decrease in chlorophyll contents directly affects the net $\mathrm{CO}_{2}$ assimilation rate as it decreases in plants under water stress $[9,23]$. In this study, total phenolic content decreased significantly in all three species under both MWD and SWD and the highest decrease was observed in Acacia modesta. These results are in line with the previous studies where reduction in chlorophyll and total phenolic content in response to water deficit reported in olives and Conocarpus under drought stress $[10,14]$. Furthermore, proline content remained similar to control under MWD and increased insignificantly under SWD in all the three species (Table 2). In this study, proline content was found highest in Acacia modesta. Increase in proline contents under water limiting environment has been observed previously in other tree species like oaks and, has been linked with the protection the plant cells from ROS damage [47]. Moreover, it has been observed that increase in the accumulation of proline under soil water deficit helps protecting the cells from dehydration and is also involved in the activation of antioxidant defense mechanisms in plants against abiotic stress [48]. Therefore, in this study, increase in proline content under MWD supports this hypothesis but under SWD, even significant increase proline contents resulted in reduced total dry weight production in all the three species.

\subsection{Intraspecific Variability and Role of Antioxidants in Stress Tolerance}

Cell membrane is highly sensitive to various abiotic stresses and increase in electrolyte leakage (EL) percentage is the indirect method of measuring the cellular damage. In this study we found a significant increase in EL percentage in all three species under both MWD and SWD treatments as compared to control conditions (Figure 2). These results are consistent with the findings on Cassia occidentalis where a significant increase in EL percentage has been evidenced under water stress [49]. Furthermore, EL percentage was found the highest in Salix tetrasperma under SWD which shows a high membrane sensitivity of Salix tetrasperma to high water stress. It has been demonstrated in the previous studies that increase in membrane damage reflects an increase in the production of $\mathrm{ROS}$ like $\mathrm{H}_{2} \mathrm{O}_{2}$ and $\mathrm{O}^{2-}$ that injures the cellular organelles, protein structure, nucleic acid fragmentation that impairs other physiological processes [50]. Such oxidative burst also causes an increase in the MDA content that reflects the peroxidation of membrane lipids [51]. In this study, significant increase in $\mathrm{H}_{2} \mathrm{O}_{2}, \mathrm{O}^{2-}$ and MDA under both MWD and SWD treatments supports this hypothesis. Similar results have been observed in the previous studies on $P$. kangdingensis and P. cathayana where drought stress resulted in increased production of $\mathrm{H}_{2} \mathrm{O}_{2}$ and MDA [17]. In order to cope with the increased production of ROS, plants have developed a complex defense mechanism of antioxidative enzymes (SOD, CAT, POD, and APX) and non-enzymatic antioxidants (ascorbic acid, anthocyanin, alpha tocholpherol, and proline; [19]. In previous studies, drought tolerance in plants has been linked to an efficient protective mechanism of enzymatic and non-enzymatic antioxidants against ROS production $[19,31,41]$. In plants, increased activity of antioxidant enzyme may support in decreasing the ROS however, the increase in the production of antioxidant enzymes depend upon the intensity and duration of stress [50]. Reduction/elimination of $\mathrm{O}^{2-}$ and $\mathrm{H}_{2} \mathrm{O}_{2}$ in plant cells requires concerted action of antioxidants where SOD scavenge the $\mathrm{O}^{2-}$ and CAT mainly neutralizes them thus, helping in ameliorating the detrimental effects of oxidative stress [18,52]. In this study, significant increase in production of antioxidants under both water deficit treatments supports this hypothesis (Figure 3). According to the previous studies, $\mathrm{SOD}$ is considered as first line of defense against the production of $\mathrm{O}^{2-}$ as it converts it to $\mathrm{H}_{2} \mathrm{O}_{2}$ which is then eliminated by CAT, POD, and other antioxidants $[53,54]$. 
In this study, the observed increase in SOD was accompanied by the increase in POD and CAT in all three species which supports this argument. In this study, the concurrent increase of antioxidant enzyme activity in all the species showed an efficient detoxication mechanism even under SWD treatment [23]. Furthermore, in this study other compatible solutes like proline also increased significantly water deficit, which are considered important in lowering the osmotic potential and thus help sustaining the physiological and growth processes [48]. A large interspecific and genetic variability regarding drought stress tolerance has been noticed previously in woody plant species and within Salix genus [18,55]. In this study, interspecific variability was observed in the activation of antioxidant defense mechanism where production of antioxidants was the highest in Acacia modesta and was the lowest in Salix tetrasperma. Moreover, increased production of antioxidants and osmolytes like proline and total phenolic content in oxidative stress seems to be involved in the tolerance mechanism under water deficit conditions [19]. Taken together, these findings show that these three species can tolerate the medium water stress in which increased root: shoot ratio together with increased production of antioxidants helped plants to sustain dry weight production at young sapling stage. We were able to demonstrate that an effective antioxidative system and production of osmolytes may play a key role in species tolerance to medium soil water deficit. However, severe water deficit tolerance was linked to a significant loss in dry weight production.
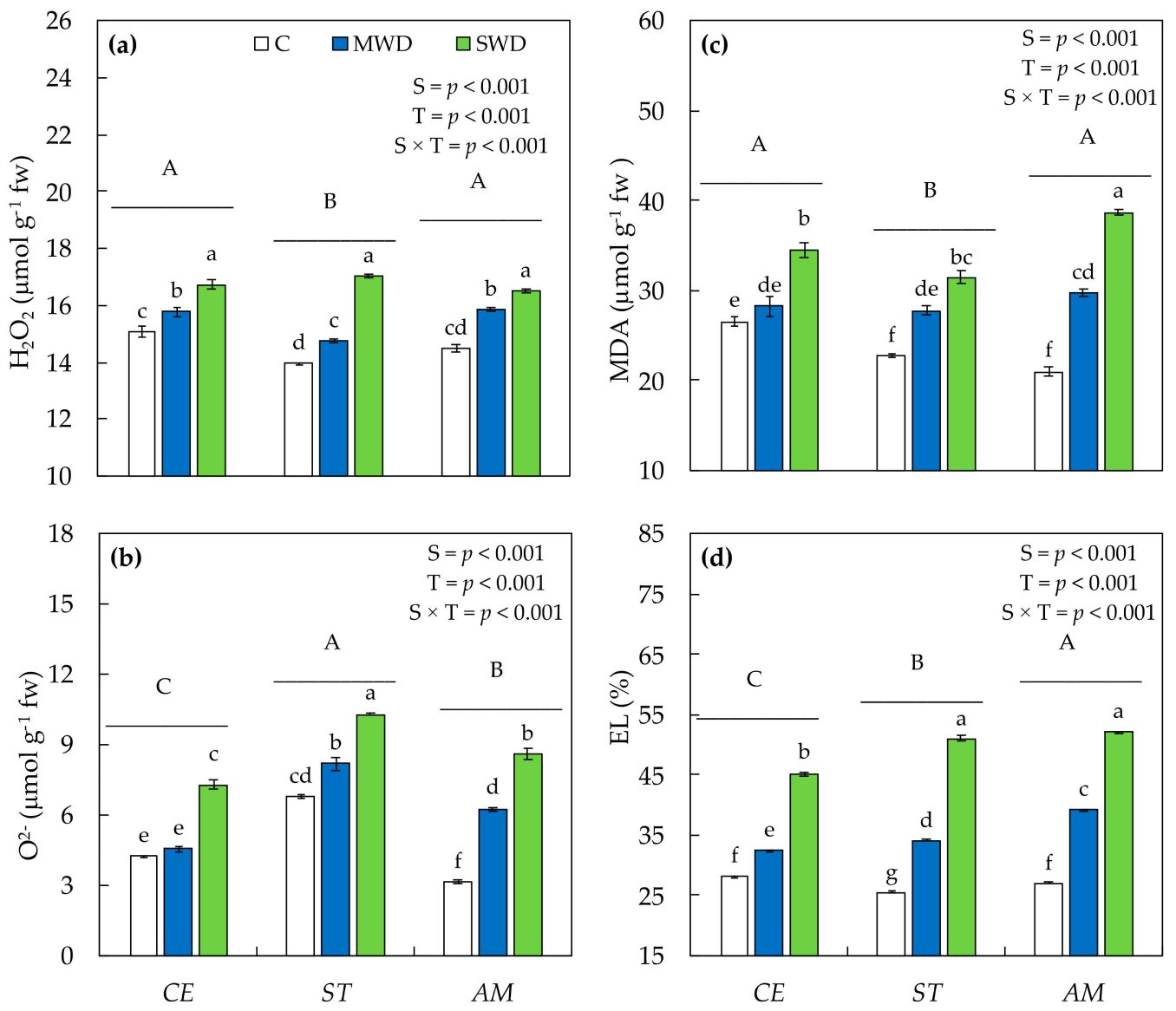

Figure 2. Mean concentration of oxidants (a) hydrogen peroxide, $\mathrm{H}_{2} \mathrm{O}_{2}$, (b) Superoxide radical, $\mathrm{O}^{2-}$, (c) Malondialdehyde, MDA and (d) Electrolyte leakage, EL in three tree species Conocarpus erectus (CE), Salix tetrasperma (ST) and Acacia modesta $(A M)$ under control (C), medium soil water deficit (MWD) and severe soil water deficit (SWD) treatments. Traits were analysed using two-way ANOVA for species $(\mathrm{S})$, treatment $(\mathrm{T})$ and interation effect $(\mathrm{S} \times \mathrm{T})$. Small letters represent pair wise differences between treatments and capital letters represent significant differences among species using post-hoc Tukey's test at $p<0.05$. Error bars are the standard errors. 

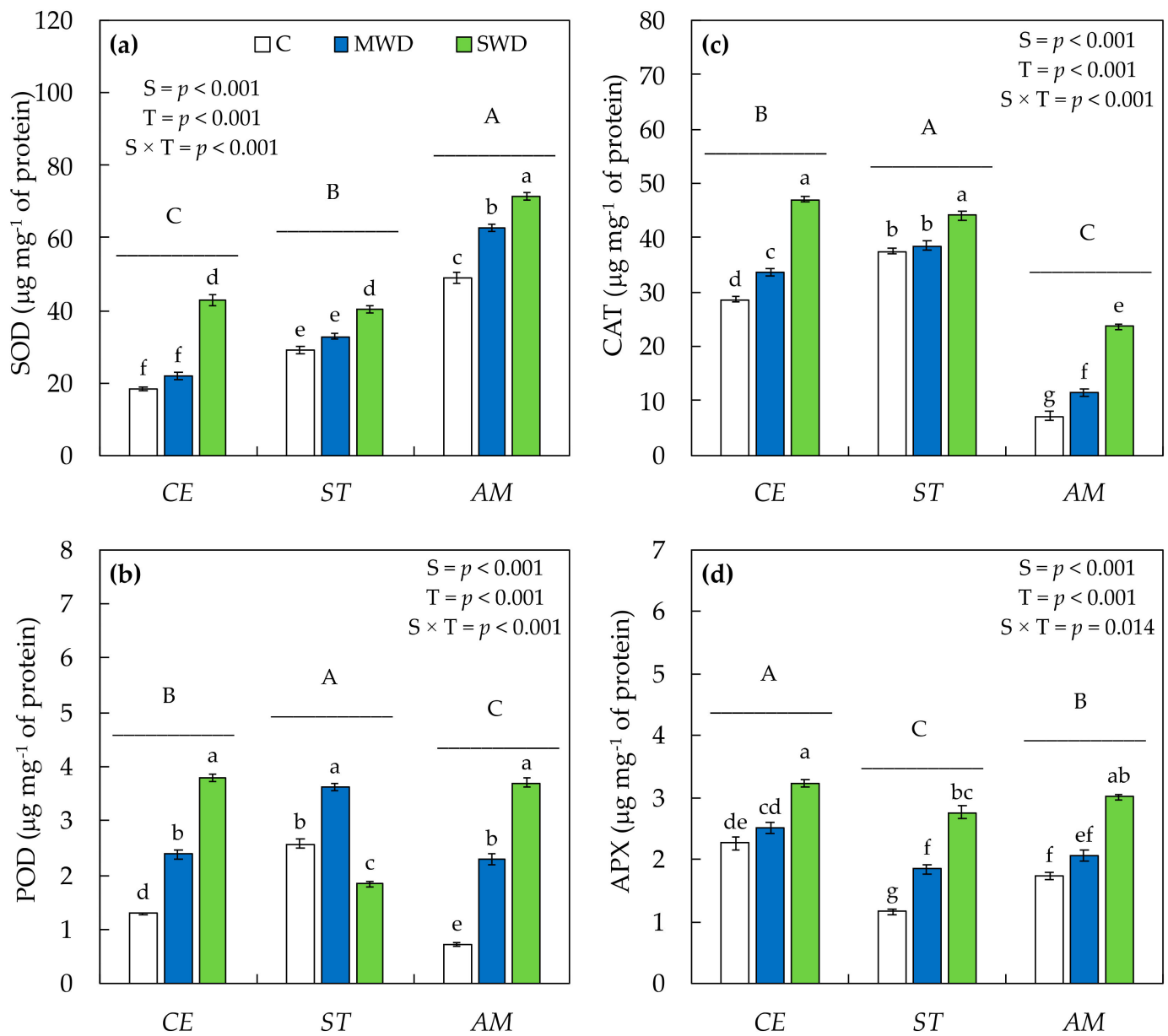

Figure 3. Mean concentration of antioxidants (a) superoxide dismutase, SOD, (b) peroxidase, POD, (c) catalase, CAT and (d) Ascorbate peroxidase, APX in three tree species Conocarpus erectus (CE), Salix tetrasperma (ST) and Acacia modesta $(A M)$ under control (C), medium soil water deficit (MWD) and severe soil water deficit (SWD) treatments. Traits were analysed using two-way ANOVA for speices $(S)$, treatment $(\mathrm{T})$ and interation effect $(\mathrm{S} \times \mathrm{T})$. Small letters represent pair wise differences between treatments and capital letters represent significant differences among species using post-hoc Tukey's test at $p<0.05$. Error bars are the standard errors.

\section{Conclusions}

In this study, we compared the tolerance mechanism in young plants of Conocarpus erectus, Acacia modesta and Salix tetrasperma under soil water deficit conditions. The results showed that all the three species were able to tolerate the MWD as total dry weight production remained similar to control under this treatment. A significant decrease in total dry weight was observed in all the tree species under SWD treatment however, the lowest decrease in total dry weight was evidenced in Acacia modesta. Similarly, chlorophyll and total phenolic contents decreased while proline content significantly increased under SWD. The significant increase in the concentration of antioxidants (SOD, POD, CAT, and APX) was accompanied with the increase in concentration of MDA, EL percentage and oxidants $\left(\mathrm{H}_{2} \mathrm{O}_{2}, \mathrm{O}^{2-}\right)$ under both MWD and SWD treatments. The results showed that under MWD, increased concentration of antioxidants helped scavenging the production of oxidants and sustaining total dry weight in all the three species. In SWD treatment, the highest concentration of antioxidants and lowest decrease in total dry weight was observed in Acacia modesta thus showing a better tolerance to soil water deficit. However, the study was conducted on young saplings under controlled conditions. Therefore, field experiments will be necessary before recommending species for planting in soil with limited water availability. 
Author Contributions: Data curation, M.F.N. and K.A.; formal analysis, M.A.; investigation, S.A. (Shazia Afzal); methodology, K.A.K. and C.D.; software, W.R.K., A.M.M.P., and S.A. (Seemab Akram); supervision, F.R.; validation, Z.Z. and F.H.I.; writing-original draft, A.G.; writing-review \& editing, F.R. and M.N. All authors have read and agreed to the published version of the manuscript.

Funding: This research received funding from Higher Education Commission (HEC), Islamabad under SIOP project and Universiti Putra Malaysia (UPM).

Institutional Review Board Statement: Not applicable

Informed Consent Statement: Not applicable

Data Availability Statement: The data presented in this study are available on request from the corresponding author

Acknowledgments: We are thankful to Rana Muhammad Atif, Plant Breeding and Genetics, University of Agriculture, Faisalabad for providing lab facilities and technical support during the biochemical analysis. We are also thankful to the anonymous reviewers for improving our manuscript and thankful of University of Putra Malaysia (UPM) researcher for being supportive.

Conflicts of Interest: The authors declare no conflict of interest.

\section{References}

1. Trenberth, K.E.; Dai, A.; Van der Schrier, G.; Jones, P.D.; Barichivich, J.; Briffa, K.R.; Sheffield, J. Global warming and changes in drought. Nat. Clim. Chang. 2014, 1, 17-22. [CrossRef]

2. Allen, C.D.; Macalady, A.K.; Chenchouni, H.; Bachelet, D.; McDowell, N.; Vennetier, M.; Kitzberger, T.; Rigling, A.; Breshears, D.D.; Hogg, E.H.; et al. A global overview of drought and heat-induced tree mortality reveals emerging climate change risks for forests. For. Ecol. Manag. 2010, 259, 660-684. [CrossRef]

3. Bothe, O.; Klaus, F.; Xiuhua, Z. Precipitation climate of Central Asia and the large-scale atmospheric circulation. Theor. Appl Climatol. 2012, 108, 345-354. [CrossRef]

4. Choat, B.; Timothy, J.B.; Craig, R.B.; Remko, A.D.; Rosana, L.; Belinda, E.M. Triggers of tree mortality under drought. Nature 2018, 558, 531-539. [CrossRef]

5. Rasheed, F.; Dreyer, E.; Richard, B.; Brignolas, F.; Montpied, P.; Le Thiec, D. Genotype differences in13C discrimination between atmosphere and leaf matter match differences in transpiration efficiency at leaf and whole-plant levels in hybridPopulus deltoides $\times$ nigra. Plant Cell Environ. 2012, 36, 87-102. [CrossRef]

6. Rasheed, F.; Delagrange, S. Acclimation ofBetula alleghaniensisBritton to moderate soil water deficit: Small morphological changes make for important consequences in crown display. Tree Physiol. 2016, 36, 1320-1329. [CrossRef]

7. Sabir, M.A.; Rasheed, F.; Zafar, Z.; Khan, I.; Nawaz, M.F.; Haq, I.U.; Bilal, M. A consistent CO2 assimilation rate and an enhanced root development drives the tolerance mechanism in Ziziphus jujuba under soil water deficit. Arid. Land Res. Manag. 2020, 34, 392-404. [CrossRef]

8. $\quad$ Rasheed, F.; Dreyer, E.; Richard, B.; Brignolas, F.; Brendel, O.; Le Thiec, D. Vapour pressure deficit during growth has little impact on genotypic differences of transpiration efficiency at leaf and whole plant level: An example from Populus nigra L. Plant Cell Environ. 2015, 38, 670-684. [CrossRef]

9. Flexas, J.; Medrano, H. Drought-inhibition of photosynthesis in C3 plants: Stomatal and non-stomatal limitations revisited. Ann. Bot. 2002, 89, 183-189. [CrossRef]

10. Zafar, Z.; Rasheed, F.; Abdullah, M.; Salam, M.M.A.; Mohsin, M. Effects of water deficit on growth and physiology of young Conocarpus erectus L. and Ficus benjamina L. Saplings. Bangladesh J. Bot. 2019, 48, 1215-1221. [CrossRef]

11. Pinheiro, C.; Chaves, M. Photosynthesis and drought: Can we make metabolic connections from available data? J. Exp. Bot. 2010, 62, 869-882. [CrossRef] [PubMed]

12. Rahmati, M.; Mirás-Avalos, J.M.; Valsesia, P.; Lescourret, F.; Génard, M.; Davarynejad, G.H.; Bannayan, M.; Azizi, M.; Vercambre, G. Disentangling the Effects of Water Stress on Carbon Acquisition, Vegetative Growth, and Fruit Quality of Peach Trees by Means of the QualiTree Model. Front. Plant Sci. 2018, 9, 3. [CrossRef] [PubMed]

13. Ben Ahmed, C.; Ben Rouina, B.; Sensoy, S.; Boukhris, M.; Ben Abdallah, F. Changes in gas exchange, proline accumulation and antioxidative enzyme activities in three olive cultivars under contrasting water availability regimes. Environ. Exp. Bot. 2009, 67, 345-352. [CrossRef]

14. Hessini, K.; Martínez, J.P.; Gandour, M.; Albouchi, A.; Soltani, A.; Abdelly, C. Effect of water stress on growth, osmotic adjustment, cell wall elasticity and water-use efficiency in Spartina alterniflora. Environ. Exp. Bot. 2009, 67, 312-319. [CrossRef]

15. Das, K.; Roychoudhury, A. Reactive oxygen species (ROS) and response of antioxidants as ROS-scavengers during environmental stress in plants. Front. Environ. Sci. 2014, 2, 53. [CrossRef]

16. Sharma, P.; Jha, A.B.; Dubey, R.S.; Pessarakli, M. Reactive Oxygen Species, Oxidative Damage, and Antioxidative Defense Mechanism in Plants under Stressful Conditions. J. Bot. 2012, 2012, 1-26. [CrossRef] 
17. Yin, C.; Peng, Y.; Zang, R.; Zhu, Y.; Li, C. Adaptive responses of Populus kangdingensis to drought stress. Physiol. Plant. 2005, 123, 445-451. [CrossRef]

18. Liu, C.; Liu, Y.; Guo, K.; Fan, D.; Li, G.; Zheng, Y.; Yu, L.; Yang, R. Effect of drought on pigments, osmotic adjustment and antioxidant enzymes in six woody plant species in karst habitats of southwestern China. Environ. Exp. Bot. 2011, 71, 174-183. [CrossRef]

19. Laxa, M.; Michael, L.; Wilena, T.; Kamel, C.; Karl, J.D. The role of the plant antioxidant system in drought tolerance. Antioxidants 2019, 8, 94. [CrossRef]

20. Yang, Y.; Han, C.; Liu, Q.; Lin, B.; Wang, J. Effect of drought and low light on growth and enzymatic antioxidant system of Picea asperata seedlings. Acta Physiol. Plant. 2008, 30, 433-440. [CrossRef]

21. Centritto, M.; Brilli, F.; Fodale, R.; Loreto, F. Different sensitivity of isoprene emission, respiration and photosynthesis to high growth temperature coupled with drought stress in black poplar (Populus nigra) saplings. Tree Physiol. 2011, 31, 275-286. [CrossRef] [PubMed]

22. Rasheed, F.; Zafar, Z.; Waseem, Z.A.; Rafay, M.; Abdullah, M.; Salam, M.M.A.; Mohsin, M.; Khan, W.R. Phytoaccumulation of Zn, $\mathrm{Pb}$, and $\mathrm{Cd}$ in Conocarpus lancifolius irrigated with wastewater: Does physiological response influence heavy metal uptake? Int. J. Phytoremediation 2020, 22, 287-294. [CrossRef] [PubMed]

23. Hussain, Z.; Rasheed, F.; Tanvir, M.A.; Zafar, Z.; Rafay, M.; Mohsin, M.; Pulkkinen, P.; Ruffner, C. Increased antioxidative enzyme activity mediates the phytoaccumulation potential of $\mathrm{Pb}$ in four agroforestry tree species: A case study under municipal and industrial wastewater irrigation. Int. J. Phytoremediation 2020, 1-11. [CrossRef] [PubMed]

24. Aslam, M. Salt affected soils options for rehabilitation. Pak. J. Soil Sci. 2002, 21, 119-126.

25. Salinger, J. Climate Variability and Change: Past, Present and Future-An Overview. Clim. Chang. 2005, 70, 9-29. [CrossRef]

26. Nazir, N.; Olabisi, L.S.; Ahmad, S. Forest Wood Consumption and Wood Shortage in Pakistan: Estimation and Projection through System Dynamics. Pak. Dev. Rev. 2018, 57, 73-98. [CrossRef]

27. Nahla, A.A. A Trimethoxyellagic acid glucuronide from Conocarpus erectus leaves: Isolation, characterization and assay of antioxidant capacity. Pharm. Biol. 2010, 48, 328-332.

28. Humaid, A.; Moftah, A.E. Effects of hydrophilic polymer on the survival of Buttonwood seedlings grown under drought stress. $J$ Plant Nutr. 2007, 1, 53-66. [CrossRef]

29. Baquar, S.R. Medicinal and Poisonous Plants of Pakistan; Printas: Karachi, Pakistan, 1989.

30. Khayya, M.T.; El-Ghazaly, M.A.; Abdallah, D.M.; Okpanyi, S.N.; Kelber, O.; Weiser, D. Mechanism involved in the an-tiinflammatory effect of a standardized willow bark extract. Arzneimittelforschung 2005, 55, 677-687.

31. Jia, H.; Wang, L.; Li, J.; Sun, P.; Lu, M.; Hu, J. Physiological and metabolic responses of Salix sinopurpurea and Salix su-chowensis to drought stress. Trees 2020, 34, 563-577. [CrossRef]

32. Arnon, D.I. Copper enzymes in isolated chloroplasts. Polyphenoloxidase in Beta vulgaris. Plant Physiol. 1949, 24, 1-15. [CrossRef] [PubMed]

33. Ainsworth, E.; Gillespie, K.M. Estimation of total phenolic content and other oxidation substrates in plant tissues using FolinCiocalteu reagent. Nat. Protoc. 2007, 2, 875-877. [CrossRef] [PubMed]

34. Bates, L.S.; Waldren, R.P.; Teare, I.D. Rapid determination of free proline for water-stress studies. Plant Soil 1973, 39, $205-207$. [CrossRef]

35. Hodges, D.M.; Delong, J.M.; Forney, C.F.; Prange, R.K. Improving the thiobarbituric acid-reactive-substances assay for estimating lipid peroxidation in plant tissues containing anthocyanin and other interfering compounds. Planta 1999, 207, 604-611. [CrossRef]

36. Nayyar, H. Accumulation of osmolytes and osmotic adjustment in water-stressed wheat (Triticum aestivum) and maize (Zea mays) as affected by calcium and its antagonists. Environ. Exp. Bot. 2003, 50, 253-264. [CrossRef]

37. Velikova, V.; Yordanov, I.; Edreva, A. Oxidative stress and some antioxidant systems in acid rain-treated bean plants protective role of exogenous polyamines. Plant Sci. 2010, 151, 59-66. [CrossRef]

38. Bai, T.; Li, C.; Ma, F.; Feng, F.; Shu, H. Responses of growth and antioxidant system to root-zone hypoxia stress in two Malus species. Plant Soil 2009, 327, 95-105. [CrossRef]

39. Fu, J.; Huang, B. Involvement of antioxidants and lipid peroxidation in the adaptation of two cool-season grasses to lo-calized drought stress. Environ. Exp. Bot. 2001, 45, 105-114. [CrossRef]

40. Nakano, Y.; Asada, K. Hydrogen Peroxide is Scavenged by Ascorbate-specific Peroxidase in Spinach Chloroplasts. Plant Cell Physiol. 1981, 22, 867-880. [CrossRef]

41. Savage, J.A.; Cavender-Bares, J.M. Contrasting drought survival strategies of sympatric willows (genus: Salix): Conse-quences for coexistence and habitat specialization. Tree Physiol. 2011, 31, 604-614. [CrossRef]

42. Chaves, M.; Pereira, J.S.; Maroco, J.; Rodrigues, M.L.; Ricardo, C.P.P.; Osório, M.L.; Carvalho, I.; Faria, T.; Pinheiro, C. How Plants Cope with Water Stress in the Field? Photosynthesis and Growth. Ann. Bot. 2002, 89, 907-916. [CrossRef] [PubMed]

43. Muller, B.; Pantin, F.; Génard, M.; Turc, O.; Freixes, S.; Piques, M.; Gibon, Y. Water deficits uncouple growth from photosynthesis, increase $C$ content, and modify the relationships between $C$ and growth in sink organs. J. Exp. Bot. 2011, 62, 1715-1729. [CrossRef] [PubMed]

44. Poorter, H.; Niklas, K.J.; Reich, P.B.; Oleksyn, J.; Poot, P.; Mommer, L. Biomass allocation to leaves, stems and roots me-ta-analyses of inter specific variation and environmental control. N. Phytol. 2012, 193, 30-50. [CrossRef] [PubMed] 
45. Hartmann, H. Will a 385 million year-struggle for light become a struggle for water and for carbon? - How trees may cope with more frequent climate change-type drought events. Glob. Chang. Biol. 2010, 17, 642-655. [CrossRef]

46. Chaves, M.; Maroco, J.P.; Pereira, J.S. Understanding plant responses to drought — from genes to the whole plant. Funct. Plant Biol. 2003, 30, 239-264. [CrossRef]

47. Cotrozzi, L.; Remorini, D.; Pellegrini, E.; Landi, M.; Massai, R.; Nali, C.; Guidi, L.; Lorenzini, G.; Lorenzo, C.; Damiano, R.; et al. Variations in physiological and biochemical traits of oak seedlings grown under drought and ozone stress. Physiol. Plant. 2016, 157, 69-84. [CrossRef]

48. Szabados, L.; Savoure, A. Proline: A multifunctional amino acid. Trends. Plant. Sci. 2010, 15, 89-97. [CrossRef]

49. Srivastava, S.; Srivastava, M. Growth response and antioxidant enzyme activity of Cassia occidentalis exposed to soil moisture stress. Biolife 2015, 3, 519-523. [CrossRef]

50. Lei, Y.; Yin, C.; Li, C. Differences in some morphological, physiological, and biochemical responses to drought stress in two contrasting populations of Populus przewalskii. Physiol. Plant. 2006, 127, 182-191. [CrossRef]

51. Tschaplinski, T.J.; E Abraham, P.; Jawdy, S.; E Gunter, L.; Martin, M.Z.; Engle, N.L.; Yang, X.; Tuskan, G. The nature of the progression of drought stress drives differential metabolomic responses in Populus deltoides. Ann. Bot. 2019, 124, 617-626. [CrossRef]

52. Mullineaux, P.M.; Baker, N.R. Oxidative Stress: Antagonistic Signaling for Acclimation or Cell Death? Plant Physiol. 2010, 154, 521-525. [CrossRef] [PubMed]

53. Silva, P.A.; Oliveira, I.V.; Rodrigues, K.C.B.; Cosme, V.S.; Bastos, A.J.R.; Detmann, K.S.C.; Cunha, R.L.; Festucci-Buselli, R.A.; DaMatta, F.M.; Pinheiro, H.A. Leaf gas exchange and multiple enzymatic and non-enzymatic antioxidant strategies related to drought tolerance in two oil palm hybrids. Trees 2015, 30, 203-214. [CrossRef]

54. Yang, F.; Miao, L.F. Adaptive responses to progressive drought stress in two poplar species originating from different al-titudes. Silva Fennica 2010, 44, 23-37. [CrossRef]

55. Bonosi, L.; Ghelardini, L.; Weih, M. Growth responses of 15 Salix genotypes to temporary water stress are different from the responses to permanent water shortage. Trees 2010, 24, 843-854. [CrossRef] 